\title{
Analysis Of Gender Stereotypes In Movies
}

\author{
Seema Manzoor \\ \& \\ Dua-e-Rehma \\ Women's Studies \\ University of Karachi \\ Samina Rauf \\ Department of Social Work \\ University of Karachi
}

\begin{abstract}
Structure of the society is the arrangement of various factors on the basis of traditions and ethics, and these values are transferred from generation to generation. The most important thing is that the pattern of the society should be balanced, which is obviously not practical in our society as this trend is seen in all aspects of our life. Media is a very important institution, yet it has not portrayed women in positive manner. If we see film medium, women are represented as sex object and commodity in a stereotypical roles. This under representation of women in movies created imbalance in the society, yet it also embeds a negative and inferior image of women in people's mind. In this study, to highlight these issues library research and content analysis is used to analyze gender stereotype in movies because women are projected and used as commodity in movies which distorts their image.
\end{abstract}

Key Words: Media, Stereotype Roles, Gender, Women Representation.

$$
\begin{aligned}
& \text { تلخيص }
\end{aligned}
$$

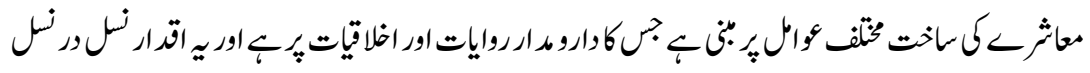

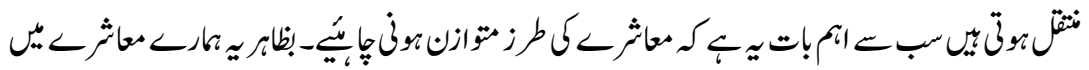

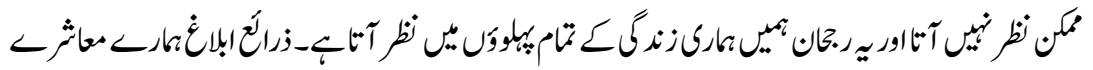

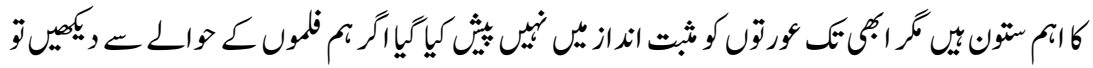

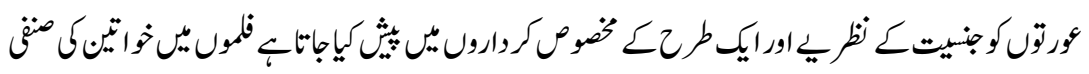

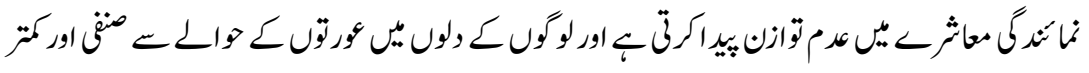

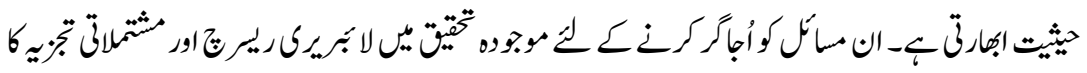

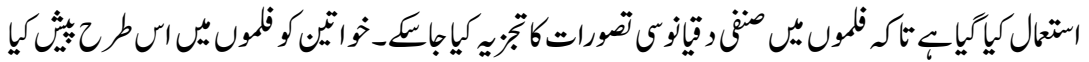

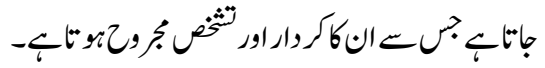

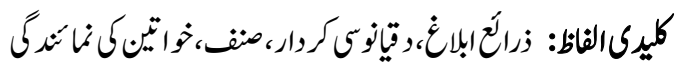




\section{Introduction}

Societies arrange themselves in many ways to interact with their cultural surroundings on the basis of their traditions and ethics. Traditional knowledge, behaviours and family values are passed on generation to generation in order to retain social and moral values, and we all learn these patterns throughout our lives. And this ongoing learning process creates our social and private identity by means of culture and language. In this contemporary world media is the fastest means of communication and information in the masses, and it helps in shaping our attitudes, behaviours and opinion. Media leaves its impact on our cultural, political and economic life also, it even shapes gender roles in the society, but with all this women are ignored and projected in few stereotypical roles and this seems to be a global issue. To highlight and create understanding regarding this issue first we need to identify the issues which women face globally. Even in Pakistan media has become a very strong pillar of society due to changing technological trends, fast communication and growing economies. Invasion of private and commercial radio and television medium is providing information to aware people, but this information can be both positive and negative. Today media can influence people and can shape their ideas, attitudes and can also reshape their concepts, but unfortunately some communication mediums do not follow the codes of conduct because they want their ideas to be absorbed by the common people as quick as possible. This stereotypical representation of media is transforming assumptions into realities, which is creating a huge gap between classes, inequalities and injustice in the society. Media is not playing its positive role as they even project and justify the actions of powerful people instead of condemning them. Stereotypical media portrayal of women is creating highly desirable, but unattainable image of women in the minds of the general public. Image of perfect body, skin and hair along with perfect personalities is lowering the respect of women at workplace and in the society. This unrealistic approach is prevailing negative impact on society and portraying women as object or commodity. Instead of portraying the high esteemed image of women media is damaging their image in the society. Portrayal of women's image in entertainment media has become a global issue, as women are presented in typical roles which badly damage their sanctity. This issue can be resolved by gender sensitized training of media personnel and journalists by projecting the real issues of women which they face for their survival. First of all we should see the factors which misinterpret women in our society. Educating society to respect women and creating awareness among women regarding biased attitude of society towards them is also an important factor in resolving this issue. Just like every other field women here also have fewer opportunities in the media industry, therefore, lack of decision making power and support hinders their way in attaining the higher positions in the media to gain the respect and status they deserve in this field (Ahmar \& Uks, 2011). 
Role of media can be used effectively by delivering right piece of information among masses because it creates a huge impact on people. Through advertisement, news, expert's opinion, music and other forms can bring positive change if used as an effective tool. Social, moral, ethical and character building can be done through the media by defining guidelines for projecting true face of society with a concept of educating people in the right dimension. Instead of expending money totally on the commercial aspect, media is also responsible for shaping society (Sharma, 2012). Women are always demoralized while playing any kind of role in movies, whether lead role or side role. Their roles are stereotypical within the set parameters of culture and society and they are used as a commodity to sell a product only (Neelam and Nasrene, 1991). Women are projected as submissive and dependent being, and in some cases, they are not even treated as humans (Pervaiz, n.d.). McNeil (1975) said that in classical and fiction based movies women are not projected in real characters, they are represented as traditional female even if they are working women and their activities are shown family oriented.

Gallagher (1979) identifies that women are projected in extreme roles either perfectly good or totally evil like a mother or a whore, pure or call girl, traditional or modern. Similarly Kunchenhoff (1975) pointed out that women are shown in the context of social relationships, their individuality is never highlighted. Whereas, Adnan (1987) says women are always represented as a negative part of society. Media shows male dominance rather promotes this mindset and women have to bear whatever is given to them by a male counterpart. They have to remain obedient and sincere in any case to show their loyalty and purity (Fernandez, 1992). Females cannot raise their voice and have to face the male aggression, thus, accepting male supremacy (Kalis and Neueddorf, 1989). According to Busby and Durkin (1985) males are more violent and females are the prime victim of their aggression.

\section{Media and Women: Representation and Portrayal}

Media today is a very important part of our life, because present age depends on technology. Earlier communication was not that easy and fast, but now it has become a necessity around the world. But the use of technology is gender biased as women are projected as a sex symbol (TRIMUNC, 2016). Film medium represents women and racial minorities of low status, whereas, men are represented as superior. Such biases captures the attention of society which is already gender biased, thus leaving a negative impact on young people and they accept it as reality and practice the same in their real life. Such factors shape and designs the society in which we live, therefore, media should realize the fact and must portray women as equal partners and functional part of the society (Murphy, 2015:4). Women's movements in the 1960's made a drastic effect and women gained liberation almost 
in all aspects of life, but we can see the same mindset in different media mediums that is controlling women's life and maintaining male supremacy (Dutt, 2014). As a result of feminist movements women have made great progress, but media culture has changed our identities as male and female (Flew, 2007).

\section{Theoretical Framework}

Few theories like Social Cognitive Theory and Cultivation Theory interprets the understanding of the audience about the gender and ethnical representation in movies. Social Cognitive Theory explains the psyche of humans that people find the solution of their real world issues through media via entertainment medium (Hall et al., 2012). In another research Johnsons and Holmes have supported the Social Cognitive Theory while analyzing romantic comedy films regarding the representation of relationships; they said people apply the situations in their real life which they observe in movies (Johnson and Holmes, 2009:353). People usually follow movies to resolve their situations because they consider it as practical demonstration of their real life issues (Eyal, Raz, \& Levi, 2014). Whereas, Bussey and Bandura (1999:676) identifies that in films societal stereotyping is shown very strongly without realizing that it will create more imbalanced society, and people seek way-out of their problems through them. Media must cultivate people's mind and should portray a realistic approach rather than deforming the relationships in society.

It is seen that usually in any film female characters are less as compared to male characters in the entire film cast; it is because females are male dependant and stereotypical representation of females in films (Feminist Frequency, 2009). According to the research of Sharma and Sender the findings clearly demonstrate that at the time of casting female characters are not considered important. In 2013 out of 50 films only 17 films projected women in a positive way, which identifies that even after gaining liberation women are underrepresented in all aspects of life (Sharma \& Sender, 2014). It is a fact that women are underrepresented, as we can see that even at prime time shows men are represented three times more than women (Basow, 1992:159). Gray and Stroman pointed out that, minorities hardly get a chance to contribute and add their part in media Stroman (1989), or we can say that it seems like that they do not even exist (O'Connor, 1989). And even if minorities are included in the cast than they are shown as lazy or unlawful and women are shown as sex object. David has also criticized media's biasness on projecting women and minorities in stereotypical roles only (David Evans, 1993:10; Lichter, Lichter, Rothman, Sr. Amundson, 1987).

Few other theories like Drive theory of aggression, Cognitive theory of aggression and Feminism Theory identifies that basic goal of aggression is to harm others intentionally and the driving forces of aggression includes frustration based 
factors. The main goal of aggression is to harm someone because frustration evokes a person to do such acts which can be termed as reaction (Dollard et al., 1939). According to Aronson, (1995); Berkowitz (1989); Huesmann, (1988, 1994) usually this reaction is violence based, as it is a way do something against a person or group in order to harm them. Berger (1981) explains that violence is a way to control someone and to demonstrate the power against someone. Since women are underrepresented in movies or they are shown only in typical roles like wife, daughter, mother and girlfriend, or secretary, nurse or receptionist. They face violence and harassment whether they are house wife or working women. Minor acts of violence are not even noticed status of women is distorted sometimes intentionally and sometimes unintentionally (Gerbner, 1973; Skonrina, 1977). We have become so used to of minor violence acts that we do not even consider them as violence against women like pushing, grabbing and saying harsh words. Feminist says that violence against is women just because they are women (Hanmer ,C. J., and. Maynard, M., 1987; Roxana Carillo, 1992; Margaret Schuler, 1992; Jessie Tellis Nayak, 1989). In the male oriented society women are supposed to be obedient and are always considered as inferior to men.

\section{Review Literature}

Media is a source of information as well as an entertainment medium and it caters knowledge, ideas, behaviours and beliefs. It also defines social parameters and develops People's perspectives. Intellectuals consider it a medium of positivity and negativity, both in terms of portraying true aspects of society rather than showing fictitious concepts and it is an instrument for education and socialization. Though media has projected women's issues also, but has a negative impact on society also by showing women as sex symbols through pornography, and female body images for promotion of brands in advertisement, etc. Generally media highlights women in stereotypical roles and projecting women as wife, mother or servant to fulfill the man's demands. Media also influences people's thought process and has impacted public policy especially in last ten years. It has greatly influenced the minds of children and adolescents. Women are contributing in media like men, but they rarely attain key positions to have decision making power to influence policies regarding media. The positive role of media is to aware people regarding gender sensitization, but the media has failed to eradicate gender stereotyping. The continuous negative projection of women in media has damaged their image in the society. Portraying the negative image of women, especially in the advertisement is seen as a global trend. Women can gain empowerment only by enhancement of their skills, access to education and technology, this is the only way women can change the world's negative perspective towards them. In developing countries women do not have access to decision making power and cannot establish network to gain their empowerment. It is, therefore, needed to let women participate fully in development and growth 
process. Women's participation can be made possible only if the government makes and implement effective gender based policies (Sharma, 2012).

Rama Jha has highlighted that how the media portrays women. According to her, women can understand their issues better, but men do not even consider issues of women as issues, in fact they make fun about women's issues. She highlights that women face harassment in this field also but such issues are never dealt seriously. Rama advises women to consider their issues important to be part of the mainstream so that men cannot over power them (Jha, 1992). Media faces criticism for promoting women negatively because women's issues are not highlighted through the media, in fact, women are exploited (Sharma, 2005). With time due to globalization, political, cultural and socio-economic changes have occurred as a result public sector gained hype as compared to public sector (Roy, 2012). Women are stereotyped and presented on media as home maker (Jha and Nigam, 2007). Though time has changed but still women are considered as delight for men's eyes and are even in fashion magazines their images are sexualized (Das, 2010). Punwani accuses that TV programs and movies insults them by projecting them in an inappropriate manner (Punwani, 1988). Women are either underrepresented or shown as superwoman who manages all domestic chores single handedly (Pandey, 1991). According to shelat, media portrays women as a person engaged in cooking, child rearing bearing whereas, men are bread earners and decision makers, Shelat (1994) and women are always shown as happy housewives (Tefft, 1987). Justice (2008) is convinced that women's liberation and focusing on gender inequalities and violence against women is the most important turning point in empowering women (Justice, 2008). Choudhury discusses feminism issue and has shown great concern for women's requirements and economic independence (Choudhury, 2000). Similarly Kiran argues that without benefiting women, society cannot prosper. For this purpose media should play its vital role by showing women strong and equal to men because media's biased attitudes towards women divert them from their right path and they remain unaware of their rights (Prasad, 2005). Tomar (2011) has attempted to bridge the gap between male and female and she thinks that the media has trapped women in its structure as sexual object.

\section{Methodology}

This study focuses on the significant issues about projection of women in media, and the problems which they face regarding attitude of society towards them. Lack of education and gender sensitization are the key factors which contribute in lowering their status. Therefore, the study aims to analyze the issues that women face due to biased attitude of media and society. In this study library research and content analysis research techniques are used to reproduce material from reliable sources and references to understand and decipher existing material. Two films from Hollywood and Bollywood are selected as sample to analyze how women are projected and the roles which they play in movies. 
Results and Discussion

Content Analysis of gender representation on Selected Media

\section{Hollywood Movie}

Name: Pretty Woman

Media: Movie

Duration: 3 hours

\section{Information about the Selected Elements}

\begin{tabular}{|l|l|}
\hline Orders & \multicolumn{1}{|c|}{ Movie/Drama } \\
\hline Genera & Movie \\
\hline Appearance & Exploitation of woman's innocence \\
\hline Target Audience & Adults \\
\hline Purpose & Glamorizing prostitution \\
\hline Date/ Time & March 23, 1990 \\
\hline Language & English \\
\hline Coverage & United States \\
\hline
\end{tabular}

\section{Gender Portrayal in Media}

\begin{tabular}{|l|c|}
\hline Characters & Total no. of Persons Showed \\
\hline Males & 10 \\
\hline Females & 5 \\
\hline Children & None \\
\hline
\end{tabular}

\section{Stereotypical Presentation}

\begin{tabular}{|l|c|}
\hline \multicolumn{2}{|c|}{ Stereotypical Presentation } \\
\hline Males & Females \\
\hline Charming & Sexy \\
\hline Brave & Bold \\
\hline Strong & Thin/skinny \\
\hline Strong & Emotional \\
\hline Decent & Talkative \\
\hline Macho & Pretty \\
\hline Caring & Funny \\
\hline Sexist & Traditional \\
\hline Active & Weak \\
\hline Harsh & Devoted \\
\hline Dominating & Serving person \\
\hline
\end{tabular}




\section{Plot/ Details/Design of Pretty Woman}

One of the most famous and leading Hollywood actor Richard Gere played a character of Edward Lewis a successful business man in Los Angeles. While roaming on the Los Angeles roads Edward met a hooker Vivian Ward (Julia Roberts). Edward needed to have partner in his social events. Initially hotel manager warned her for her inappropriate behaviour but at corporate dinner Edward was very delighted to see her new look as a sophisticated lady. He started trusting Vivian and gradually revealed his life secrets on her. He took her to polo match to get some business contacts, his attorney suspected Vivian as corporate spy but Edward assures that she is just a business arrangement; she felt insulted that why Edward opened her secret on Phillip. But on Edward's confession about his jealousy towards Phillip for taking interest in her. He got attracted more and more towards Vivian and wanted to have closer relationship with her and they fell for each other. Edward offered her an apartment to live so that she can live a decent life off streets as a hooker. She felt offended because she wanted to have a normal life like a couple. Due to Vivian his way of looking towards life changed and he started working together to save corporate companies instead of gaining profit. Phillip his business associate became furious on Edward's behaviour and loss of money, he wanted to have argument with Edward but, in hotel room he met Vivian, first he blamed her then tried to take advantage of her. Edward rescued her and blamed him for his greed and lust. Vivian left Edward on such insult and later Edward realizes her importance in his life and approached her and fulfilled her dream by reaching her apartment just like a prince reaching for his beloved princess.

\section{Bollywood Movie}

Name: Umraoo Jaan Ada

Media: Movie Duration: 3 hours

Information about the Selected Elements

\begin{tabular}{|l|l|}
\hline Orders & \multicolumn{1}{c|}{ Movie/drama } \\
\hline Genera & Movie \\
\hline Appearance & Exploiting women to satisfy revenge \\
\hline Target Audience & Adults \\
\hline Purpose & Novel based movie (drama film) \\
\hline Date/ Time & January 01, 1981 \\
\hline Language & Urdu \\
\hline Coverage & India \\
\hline
\end{tabular}




\section{Gender Portrayal in Media}

\begin{tabular}{|l|c|}
\hline Characters & Total no. of Persons Showed \\
\hline Males & 8 \\
\hline Females & 4 \\
\hline Children & 1 \\
\hline
\end{tabular}

\section{Stereotypical Presentation}

\begin{tabular}{|l|c|}
\hline \multicolumn{2}{|c|}{ Stereotypical Presentation } \\
\hline Males & Females \\
\hline Man of choices & Pleasing men \\
\hline Rich & Beautiful \\
\hline Possessive & Emotional \\
\hline Strong & Weak \\
\hline Full of desires & Helpless \\
\hline Betrayal & Serving person \\
\hline Cunning & Faithful \\
\hline
\end{tabular}

\section{Plot/ Details/Design of Umraoo Jaan Ada}

The Umraoo Jaan character was played by Rekha who was born in Faizabad in a noble family and was named Amiran. Another character Dilawar Khan a criminal kidnapped Amiran to take revenge from her father because he testified against him in the court. Initially he kidnapped her for ransom but on not getting ransom money he decided to sell her in Lacknow. Another girl Ram Dai was abducted with her but they both got separated later because Dilwar Khan sold Amiran to a tawaif Khanum Jaan in 150 Rupees. She was named Umraoo later by Khanum and begins to learn poetry, music and dance. Umraoo was also taught to read and write poetry in Urdu and Persian. She after gaining maturity age got his first client and earned the suffix of "Jaan". Umraoo fell in love with a handsome and rich Nawab named Sultan. Nawab Sultan had a fight with a jealous customer of Umraoo and shoot him and he died. After that Sultan started meeting her secretly by the help of Umraoo's friend Gauher Mirza. Umraoo kept meeting Sultan along with serving her clients. She uses to support Gauher Mirza financially. A new client Faiz Ali fell for her and gave her very precious gifts (jewels and gold). Faiz Ali invited her to travel with him but Khanum refuses, therefore, Umraoo ran away with him but, on the way to Farrukhabad she discovered that Faiz was a dacoit and all the jewels which he gifted were stolen goods. Soldiers arrested her because Faiz Ali escaped leaving her alone, but luckily one of the Khanum's tawaif rescued her. After this incident Umraoo refused to return to Khanum's 
Kotha and stayed in Kanpur. She was performing in a house of Begum in Kanpur, there Faiz Ali tried to rob the house but on seeing Umraoo there, they left. Later Gauher Mirza came to her to take her back to Khanum. Umraoo performed in the court of Wajid Ali Shah but had to leave for Faizabad due to Siege of Lacknow. She discovered her mother and family there, but due to her brother she could not return home. Her brother considered her as a disgrace for the family. In Kanpur she met Begum of Lacknow again and discovered that she was actually Ram Dai now the wife of Nawab Sultan. She then decided to retire as a tawaif to have a peaceful life with her earnings and the gold that Faiz Ali gave her.

\section{Conclusions}

According to current researches it has been analyzed that communication networks and information technology has gone far beyond our imagination, it knows no boundaries and facilitates globally. It has even impacted public and private policy patterns. Social behaviours have been transformed due to advancement in technology, especially children and adolescents shape their life's pattern on its basis. Though it seems that media has created more opportunities for women to move forward and contribute in every sphere of life. But in communication sector very few women have gained the empowerment and decision making power. Therefore, women do not get the chance of contributing policy making to influence media. Gender based stereotyping in seen in media especially because gender sensitization is not considered important worldwide. It is the need of time to change the mindset of our society in order to give respect to women which they deserve. The responsibility of media organizations is to eliminate discrimination and subordination against women. The continuous negative portrayal of women should be eliminated, because it is declining women's level of respect in the society. In fact positive projection of women can enhance their societal role and contribution to have a balanced society where women can breathe freely without any dictation and supremacy or control over them. It's not just media's role for improving women status, but it is the responsibility of governments as well to give more chances to women for improving their skills, knowledge and easy access to technology. Media is fastest growing industry, and film industry has key importance in our society due to high entertainment value. Gender roles and be re structured by the positive role of film industry. It is the biggest challenge for film industry to combat gender issues by taking positive measures. State actors can also intervene to have check and balance system against women disgrace. In this study two films are selected to analyze how women are projected and gender stereotyping. In pretty women prostitution is glamorized instead of showing that this is the dirty face of our society where women have to sell their body and soul to earn their living. In both these films women are used as commodity for the sake of entertainment. The reviews and discussion regarding these films did not condemn the subject of 
movie; in fact it was labelled as feminist classic. Overall women are considered weak and inferior and an item of sale and purchase. Such behaviour against them starts right from their birth and they face many traumas which add more misery in their lives. Negative portrayal of women in films and entertainment media is adding more sexual crimes against women because it arouses sexual appeal and lust in men. Media should focus on women issues rather than using them as sex object. Societal perception regarding working women is not pleasant, and they have to face harassment at workplace due to this negative attitude of our society. Films actually building a concept that, women should not be respected and society should have low acceptance towards them. Women are generally projected in three roles biological, household and decorative, and media is not challenging gender attitudes which are promoted and affected by the society.

\section{References}

Adnan, M.H. (1987). Women and the Media in Malaysia, Media Asia, vol. 14:4, pp.194-203.

Ahmar, T. \& Uks (Islāmābād, Pakistan). (2011). More Women in Media the Way Forward, Islamabad, Uks.

Aronson, E. (1995). The Social Animal ( $7^{\text {th }}$ Ed.), New York, W.H. Freeman and Co., Katz, Gurevitea.

Basow, S. A. (1992). Gender: Stereo-\&\& and Roles (3rd ed.), Pacific Grove, CA: Brooks/Cole.

Berger, A. A. (1981). Television As An Instrument Of Terror, New Brunwich, New Jersey.

Berkowitz, L. (1989). Roots of Aggression, New York Atherton.

Busby, L. J. (1975). Sex Role Research On The Mass Media, Journals of Communication, vol.25, pp.107-131.

Bussey, K. \& Bandura, A. (1999). Social Cognitive Theory of Gender Development and Differentiation, Psychological Review, vol.206:1, pp.676-713.

Choudhury, Maitrayee (2000). Feminism in Print Media, Indian Journal of Gender Studies, New Delhi, Sage Publications. 
COMOC, J. J. (198\% June 6). What are comme\&iaLs selling to cMMn=n? New York Times, p.28.

Das, Mallika (2000). Men and Women in Indian Magazines Advertising, Sex Roles Mt. Saint Vincent Uni, Springer US, vol.43, pp.699-717.

Dollar, J. (1939). Frustration and Aggression, New Havan, Yale University Press.

Dollard, J., Doob, L., Miller, N., Mowerer, O. H. \& Sears, R. R. (1939). Frustration and aggression, New Haven, CT, Yale University Press.

Durkin, K. (1985). Television, Sex Roles and Children, Milton Keynes, Open University Press.

Dutt, Reema (2014). Behind The Curtain: Women's Representations in Contemporary Hollywood, London, Media@LSE, London School of Economics and Political Science ("LSE").

Evans, D. (1993, March 1). The Wrong Examples, Newsweek, p. 10.

Eyal, K., Raz, Y. \& Levi, M. (2014). Messages about sex on Israeli television: Comparing Local and Foreign Programming, Journal of Broadcasting \& Electronic Media, vol.58:1, pp.42-58.

Feminist Frequency. (2009, Dec 7). The Bechdel Test for Women in Movies, retrieved from http://www.feministfrequency.com/2009/12/the-bechdeltest-for-women-inmovies/

Fernandez, I. (1992). Who Call The Shots? The Ideology of Control By The Media on Women. A Paper Presented at the Seminar on the Mass Media and Women in Malaysia, Penang, Malaysia.

Flew, Terry (2007). Understanding Global Media, Basingstoke, Palgrave Macmillan.

Gallagher, M. (1979). The Portrayal And Participation of Women in the Media, Paris UNESCO, Mimeographed, p. 9.

Gerbner, G. (1973). Cultural Indicators-the Third Voice, Communications Technology and Social Policy, Gerbner, G., Gross, L. and Meloy, W. (edr), New York, Wiley. 
Hall, P., West, J. \& McIntyre, E. (2012). Female Self-Sexualization in MySpace.com Personal Profile Photographs, Sexuality \& Culture, vol. $16: 1$, pp. 1-16.

Hanmer, C. J. \& Maynard, M. (1987). Women, Violence and Social Control, London.

Huesmann $(1988,1989)$. An Information Processing Model for the Development of Aggression, Aggressive Behaviour, vol.14, pp.13-24.

Jessie, Tellis Nayak (1989). Institutional Violence against Women in Different Cultures, In God's Image.

Jha, Jyotsna \& Nigam, Divya (2007). Women in Advertising, Changing Perception, ICFAI Uni press.

Johnson, K. \& Holmes, B. (2009). Contradictory Messages: A Content Analysis of Hollywood-Produced Romantic Comedy Feature Films, Communication Quarterly, vol. 57:3, pp. 352-373.

Justice, G.N. Ray (2008). Addressing the Press Council of India at the Inauguration Session of National Press Day on Nov, 16, at Vigyan Bhavan, New Delhi.

Kalis, P. \& Neuendorf, K. A. (1989). Aggressive Cue Prominence and Gender Participation In MTV, Journalism Quarterly, vol. 66:1, pp. 148-154.

Kunchenhoff (1975). Cited in Seema Pervaiz 'Analysis of Mass Media, Appealing to Women, National Institution of Psychology, Islamabad, p. 10.

Lichter, S. R., Lichter. L. S., Rothman, S., \& Amundson, D. (1987, July/August). Prime-Time Prejudice: TV's Images of Blacks and uspamcs. Pubhc Opinion, pp.13-18.

Margaret Schuler (1992). (ed.), Freedom from Violence. Women's Strategies from Around the World, New York.

Mcneil, J. C. (1975). Imagery of Women in T.V Dramas: Some Procedural and Interpretive Issues, in Journal of Broadcasting, vol.19:3.

Murphy, Jocelyn Nicole (2015). The Role of Women in Film: Supporting the Men -An Analysis of how Culture Influences the Changing Discourse on Gender Representations in Film, Fayetteville, University of Arkansas, p. 4. 
Neelam \& Nasrene (1991). Women, Media and the Production of Meaning in Finding Our Ways: Readings on Women in Pakistan, Asr Publication, p.175.

Pandey, M. (1991). The Subject is Women, New Delhi, Sanchar Publishing House.

Pervaiz, Seema (n.d.) Analysis of Mass Media Appealing to Women, Women's Division Government of Pakistan, Islamabad.

Prasad, Kiran. (2005). Women, Media and Society: Recasting Communication Policy, in the edited book by herself, Women and Media-Challenging Feminist Discourse, The Women's Press.

Punwani, J. (1988). Portrayal of Women in Television, Published in an Edited Book Women in Indian Society: A Reader, New Delhi, Sage Publications, pp.225-232.

Jha, Rama. (1992). Women and the Indian Print media, New Delhi, Northern Book Centre.

Roxana, Carillo (1992). Battered Dreams, Violence against Women as an Obstacle to Development, New York.

Roy, S.S. (June 2012). Portrayal of Women in Indian Media-In the Era of NeoLiberal Economy, Global Media Journal, vol.3:1.

Sharma, Dr. Sanjeev Kumar (2005). Depiction of Women in Indian Media-A Case of Introspection for Media Planners, Samaj bigyan shodh Patrica, Amroha, vol.1:1, pp.32-36.

Sharma, Arpita (2012). Portrayal of Women in Mass Media, Media Watch: 1-7.

Sharma, V. \& Sender, H. (2014, Jan 2). Hollywood Movies with Strong Female Roles Make More Money, retrieved from http:/www.vocativ.com/culture/ celebrity/hollywood-movies-strong-female-rolesmake-money/

Shelat, M. (1994). Gender Portrayals in Indian Advertising, Seminar Paper Presented to the Gender and Communication Section, International Association for Mass Communication Research Seoul, Korea.

Skornia, H. J. (1977). The Great American Teaching Machine--of Violence Intellect, p. 253. 
Stroman, C. A. (1989). To be Young, Male and Black on Prime-Time Television., Urlnn Research Review, vol. 22, pp. 9-10.

Tefft, S. (1987). India’s Bill Could Jail Advertisers, Advertising Age.

Tomar, Ranu in her Seminar Paper (2011). Gender and Media: Status of Women Journalist in Hindi Print Media in India, Presented at University of Work.

TRIMUNC (2016). Media and Women Representation and Portrayal, https://trimunc.org/committeestopics/csw/media-and-womenrepresentation-and-portrayl/, retrieved on June $1^{\text {st }}, 2016$.

Seema Manzoor is Lecturer in the Centre of Excellence for Women's Studies, University of Karachi.

Dua-e-Rehma is Lecturer in the Centre of Excellence for Women's Studies, University of Karachi.

Samina Rauf is an Assistant Professor in the Department of Social Work, University of Karachi. 